\title{
Energy requirements for nitrogen cooling systems of WBC units
}

\author{
D. Sc. A. Yu. BARANOV ${ }^{1}$, O. A. FILATOVA, A. V. VASILENOK, A. V. SAFONOV, E. V. SOKOLOVA \\ 1abaranov@corp.ifmo.ru \\ ITMO University
}

Whole-body cryotherapy (WBC) technique is based on supercooling patient's body to stimulate skin cold receptors at the depth of 0.15 мM form skin surface forming signal of maximum intensity at the temperature of $-2{ }^{\circ} \mathrm{C}$. Heat removal by gas with the temperature of not more than $-130^{\circ} \mathrm{C}$ allows localizing body supercooling zone at the depth of receptors. The research is made to estimate maximum intensity of heat removal and necessary power consumption. It allows determining requirements for power supply of WBC units that is crucial for efficiency and safety of WBC. The research is carried out by the mathematical models of WBC object (human body surface) and a unit of volume for WBC zone (patient's cabin). Implementation of WBC technique is shown to require removing $3.8 \mathrm{~kW}$ of heat from patient's body surface. Taking into account total refrigerating capacity the cryostatting system for single-seated WBC cabin has to remove as less as $6.4 \mathrm{~kW}$ of heat form the temperature level of $-130^{\circ} \mathrm{C}$. Therefore, a refrigerator of $47 \mathrm{~kW}$ power or nitrogen cooling system with refrigerating medium consumption of $0.025 \mathrm{~kg} / \mathrm{s}$ or $4.45 \mathrm{~kg}$ per procedure is necessary. The use of nitrogen cooling for $W B C$ zone results is compact and mobile single-seated WBC units. Owing to high competitive advantages single-seated units for WBC are widely used in the world, they being used in Russian clinical practice for more than 20 years.

Keywords: WBC, supercooling, heat load.

Article info:

Received 14/01/2019, accepted 28/02/2019

DOI: $10.17586 / 1606-4313-2019-18-1-92-97$

Article in English

For citation:

Baranov A. Yu., Filatova O. A., Vasilenok A. V., Safonov A. V., Sokolova E. V. Energy requirements for nitrogen cooling systems of WBC units. Vestnik Mezhdunarodnoi akademii kholoda. 2019. No 1. p. 92-97.

\section{Энергетические требования \\ к системам азотного охлаждения установок для WBC}

Д-р техн. наук А. Ю. БАРАНОВ ${ }^{1}$, О. А. ФИЛАТОВА, А. В. ВАСИЛЕНОК, А. В. САФОНОВ, Е. В. СОКОЛОВА
'abaranov@corp.ifmo.ru
Университет ИТМО

Технология whole-body cryotherapy (WВС) основана на переохлаждения поверхности тела пациента для стимуляции холодовых рецепторов кожи, которые расположены на расстоянии 0,15 мм от поверхности кожи и формируют сигналы максимальной интенсивности при температуре $-2{ }^{\circ}$. Отвод теплоты газом с температурой не выше $-130{ }^{\circ}$ С позволяет локализовать зону переохлаждения тела на уровне залегания рецепторов. Исследование выполнено для оценки оптимальной интенсивности отвода теплоты и сопутствующих затрат энергии. Исследование позволяет определить требования по энерговооруженности установок для ШВС, которая определяет эффективность и безопасность технологии ШВС. Исследование выполнено на математических моделях объекта ШВС (оболочки тела человека) и единццы объема зоны ШВС (кабины пациента). Показано, что для реализации технологии ШВС необхоцмо отводить теплоту с поверхности тела пациента 3,8 кВт. Сучетом прочих затрат холодопроизводительности, система криостатирования одноместной ШВС кабины долюна отводить не менее 6,4 кВт теплоты с температурного уровня $-130^{\circ}$ С. Это может обеспечить рефрижератор смоцностью привода 47 кВт или азотная система охлаждения с расходом криоагента 0,025 к2/с или 4,45 кг на процедуру. Использование азотного охлаждения зоны WВС обеспечивает компактность и мобильность одноместных устройств для ШВС. Благодаря высоким конкурентным преимуцествам одноместные установки для ШВС получили широкое распространение в мире, практика их клинического применения в России насчитывает более 20 лет.

Ключевые слова: WBC, переохлаждение, тепловая нагрузка.

Информация о статье:

Поступила в редакцию 14.01.2019, принята к печати 28.02.2019

DOI: $10.17586 / 1606-4313-2019-18-1-92-97$

Язык статьи - английский

Ссылка для цитирования:

Baranov A. Yu., Filatova O. A., Vasilenok A. V., Safonov V. A., Sokolova E. V. Energy requirements for nitrogen cooling systems of WBC units. // Вестник Международной академии холода. 2019. № 1. С. 92-97. 


\section{Introduction}

In the papers concerning the methods of whole-body cryotherapy (WBC) clinical effects of the procedure are paid main attention to $[1,2,3]$. The issues of procedure method choice, the temperature of cooling gas, and cooling exposition are discussed much less often $[4,5]$. The technological task of WBC technology - supercoiling of patient's body surface to subterminal temperature - is not paid attention as well. It is supercooling of the body surface in the cold receptors area that provides stimulating effect on central nervous system (CNS) of the body. The intensity and duration of the effect is crucial for the positive influence of WBC. The most obvious and controllable effect of WBC is the time of analgetic effect or effective time (ET WBC) [6]. The research carried out at ITMO University allows estimating the dependency between decreasing the temperature of patient's body surface and ET WBC value. The conditions of hypothermal safety for patients are determined. An optimal gas temperature in WBC zone is found out by numerical experiment.

However, the exploitation of WBC units proves that insufficient power of cooling system is the main issue for the systems in use [7]. It is true for the units with nitrogen cooling system where nominal consumption of liquid nitrogen do not stabilize the temperature in WBC zone. A greater power insufficiency is observed in nitrogen-free cooling systems where vapor refrigeration cycles are used to remove heat. Electrical power in these refrigerators is $5-10$ times less than it is necessary to remove heat load at the air temperature claim in WBC zone [8]. Low power of cooling system does not allow for modern multi-seater WBC units to maintain temperature at $-170^{\circ} \mathrm{C}$ as the original Japanese unit, in which cryotherapeutic effect was observed for the first time, does $[9,10]$.

The reason for the insufficient power of cooling systems for WBC units is the faulty estimating heat emission from the patient's body, poor design of the procedure cabins, and erroneous choice of the technique for heat removal from cooling gas to refrigerating medium.

Insufficient power of cooling systems is the main reason for low treatment efficiency of most modern WBC units. The temperature in $\mathrm{WBC}$ zone is unstable. In the presence of patients the temperature rises by $30-50 \mathrm{~K}$. The units cryostatted by vapor refrigeration cycles needs $8-10 \mathrm{~min}$ to regain temperature in the main cabin after each procedure [7, 11].

To solve the above issues one should provide proper insight into the real cooling system heat load in WBC zone, and to determine a refrigerator power or liquid nitrogen consumption corresponding to the heat load.

\section{Thermophysical processes in WBC systems}

WBC procedures are based on quick supercooling of patient's body surface due to heat removal to cryogenic gas. At ITMO University thermophysical theory of WBC has been developed, and an optimum degree and rate of skin surface supercooling has been determined [6]. To meet the efficiency requirements for $\mathrm{WBC}$ procedures one should remove great amount of heat form patient's body surface for a limited time. To perform this task cryostatting system of WBC unit has to exhibit refrigeration capacity at the temperature level not exceeding $-130^{\circ} \mathrm{C}[6]$.

Heat emission from patient's body surface and cooling system heat load proved to be much higher than it was expected by most manufacturers of WBC units.

\section{Thermal processes in patient's body surface during WBC procedure}

According to thermophysical theory of WBC an intensive heat removal is necessary to decrease the temperature of patient's body surface (BS) to subterminal level $t_{s} \rightarrow-2{ }^{\circ} \mathrm{C}$. Decreasing BS temperature $(T)$ results in irritation of skin cold receptors. The intensity of stimulating action (ISA) on cold receptors increases hyperbolically as the temperature nears to the terminal one $\left(t_{\text {term }}=-2.5^{\circ} \mathrm{C}\right)$.

$$
I_{s a}=\frac{1200}{\left(T_{s}-T_{\text {term }}\right)^{2}},
$$

where $T_{s}, T_{\text {term }}$ are the BS temperature and the terminal temperature $K$ correspondingly

Hyperbolical dependence between BS temperature and ISA value is that supercooling of BS to the temperatures above $275 \mathrm{~K}\left(2.0^{\circ} \mathrm{C}\right)$ irritates cold receptors negligibly. At $T_{s}=275$ $\mathrm{K}$ the value of ISA is only 60 . Cooling to $T_{s}=271 \mathrm{~K}\left(-2.0^{\circ} \mathrm{C}\right)$ gives 80 times ISA increase [7, 8, 11].

The amount of heat transferred from BS to cooling gas has been determined from calorific capacity of the body for the long time. An average calorific capacity of the body at moderate physical activity is $100 \mathrm{~W} / \mathrm{m}^{2}$ [10]. Taking into account average BS area nominal heat flow form human body is $160 \mathrm{~W}$. Under the conditions of maximum physical activity the calorific capacity may increase significantly. For example, while swimming body generates up to $700 \mathrm{~W}$ of heat. The analysis of energy indictors for WBC units in use demonstrates that heat capacity of patients body was estimated at $300 \mathrm{~W}$ on average when designing [7].

During WBC procedures the heat from supercooling BS tissues gives the main heat load. Epithelium, fat tissue, and muscles are of high density $\rho$, moisture content $\varphi$, thermal capacity $c$, and thermal conductivity $\lambda$ (Table 1 ). These physical properties of BS tissues determine their thermal inertia [11]. Specific calorific power of metabolism for particular tissues $q_{\text {met }}$ influences BS temperature to a certain extent. Metabolism heat generates distributed heat sources preventing supercooling in WBC object.

Heat removal from BS is carried out due to convection of cooling gas

Thermophysical properties of BS tissues [7]

Table 1

\begin{tabular}{|c|c|c|c|c|c|}
\hline Structure & $\rho, \mathrm{kg} / \mathrm{m}^{3}$ & $\varphi, \%$ & $c, \mathrm{~J} /(\mathrm{kg} \cdot \mathrm{K})$ & $\lambda, \mathrm{W} /(\mathrm{m} \cdot \mathrm{K})$ & $q_{m e r} \mathrm{~W} / \mathrm{kg}$ \\
\hline Epithelium & 1093 & 72,0 & 3600 & 0,35 & 10,06 \\
\hline Muscles & 1041 & 80,0 & 3458 & 0,475 & 6,99 \\
\hline Fat tissue & 916 & 20 & 2250 & 0,21 & - \\
\hline
\end{tabular}




$$
q_{s-1}=\alpha\left(T_{s}-T_{1}\right) ; \quad Q_{s-1}=\int_{\tau=0}^{\tau=\tau_{\max }} q_{s-1} \partial \tau,
$$

where $\alpha$ - heat transfer coefficient at natural gas convention, $\mathrm{W} /\left(\mathrm{m}^{2} \cdot \mathrm{K}\right)$;

$T_{s}, T_{1}$ - the temperatures of $\mathrm{BS}$ and cooling gas $\mathrm{K}$ correspondingly.

Surface temperature decreasing results in an additional heat intake by heat transfer from BS internal sections:

$$
q_{\lambda}=-\frac{\lambda\left(T_{s}-T_{1}\right)}{\Delta E},
$$

where $\Delta x$ - the interval of surface division into conditional sectors, $\mathrm{m}$.

Even moderate BS supercooling results in sharp increase of heat supply by thermal conductivity. At the interval $\Delta x=0.5 \cdot 10^{-3} \mathrm{~m}$ surface temperature decrease by $1 \mathrm{~K}$ results in heat supply by thermal conductivity with the power $q_{\lambda}$ $=700 \mathrm{BT} / \mathrm{M}^{2}$. The task performance of $\mathrm{WBC}$ is to supercool surface by $34 \mathrm{~K}$, from $305\left(32{ }^{\circ} \mathrm{C}\right)$ to $271 \mathrm{~K}\left(-2{ }^{\circ} \mathrm{C}\right)$. Therefore, it is necessary to remove $650 \mathrm{~kJ}$ of heat accumulated in $\mathrm{BS}$ tissues from BS.

The heat emission is due to supercooling of deeper BS layers along with the surface $[12,13]$. It is proved by the graphs of tissue temperature changes across the BS thickness both in the beginning and in the end of WBC procedure (Fig. 1). With distance from the surface the degree of BS tissue supercooling decreases $(\Delta t)$ from the maximum of $34^{\circ} \mathrm{C}$ at $X=0$ to $0.3^{\circ} \mathrm{C} \Delta X=15 \mathrm{~mm}$. Lowering the temperature of every BS segment is accompanied by accumulated heat emission

$$
Q_{A i}=\Delta T_{i} \Delta x \rho_{i} c_{i} .
$$

The total amount of the heat emitted due to supercooling of tissue is the sum of the heat emitted from the elementary BS segments:

$$
Q_{A}=\sum_{i=0}^{30} \Delta T_{i} \Delta x \rho_{i} c_{i}
$$

When the temperature of BS changes according to the graph presented in Fig. $1456 \mathrm{~kJ} / \mathrm{m}^{2}$ of heat accumulated

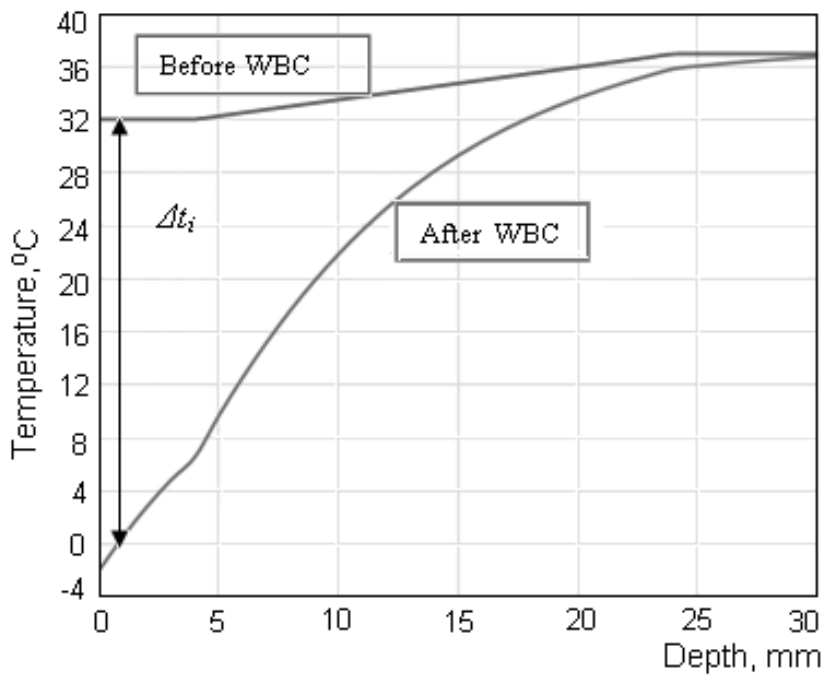

Fig. 1. The temperature distribution across patient's body surface before and after WBC procedure by BS tissues is emitted for the procedure. $476 \mathrm{~kJ} / \mathrm{m}^{2}$ of heat is removed from BS. The difference between the heat removed from BS and the temperature of BS tissue supercooling is the heat emitted due to metabolism in the patient's body

$$
Q_{m e t}=Q_{s-1}-Q_{A} .
$$

BS heat balance allows estimating heat gain from different sources. Epithelium supercooling heat gives the main part of heat load on CS $\left(280 \mathrm{~kJ} / \mathrm{m}^{2}\right.$ or $\left.59 \%\right)$. Heat of supercooling of subcutaneous tissue $-171 \mathrm{~kJ} / \mathrm{m}^{2}(35 \%)$. Supercooling of muscles gives only $6 \mathrm{~kJ} / \mathrm{m}^{2}(1.4 \%)$. Metabolism heat gives only $20 \mathrm{~kJ} / \mathrm{m}^{2}(4.6 \%)$ [13].

Monitoring body surface temperature after WBC procedures in multi-seated units shows that, due to high level of rated temperature in the main cabin, cryogenic gas is not able to remove the proper amount of heat from an object [14, 15]. In all cases the measured temperature of skin surface after the procedure was more than $10^{\circ} \mathrm{C}$. It is much higher value than it is recommended according the WBC process modeling [6]. If these requirements are not met the current research' [16] not proving the effects described by the developer in [9] is due to the fact these requirements are not met.

A small amount of heat gained from metabolism allows substantiating exploitation advantages of WBC technique. Firstly, body protection form supercooling is achieved not due to the system of thermoregulation, but due to thermal inertia of BS tissues. Therefore, WBC procedures are suitable for patients of every age and training level. Secondly, patient's system of thermoregulation is by no means necessary to be adjusted to thermal loads during WBC procedures, so there is no reason "to train" patient's body before the short-time procedures. The treatment can be started immediately stat from minimal exposition of $120 \mathrm{sec}$ [7].

The heat of supercooling and the heat of metabolism should be removed form BS for a limited time. An allowable WBC exposition is not more than $200 \mathrm{sec}$. Known time of cooling allows estimating the power of heat flow power from patient's body surface to cryogenic gas

$$
q_{s-1}=\frac{Q_{s-1}}{\tau_{\max }} .
$$

An average density of heat flow form BS is $2.38 \mathrm{~kW} / \mathrm{m}^{2}$ or $3.8 \mathrm{~kW}$ per patient. It is approximately 10 times higher the values used in calculation for actual WBC units. It should be also noted that along with the heat coming from patient's body the system of cryostatting should compensate heat gain from other sources.

\section{Sources of heat load for cooling system of $W B C$ unit}

Heat removed from patient's body is an effective load for cryostatting system. Along with effective load there are always the sources of heat which are not connected with therapeutical effect. Total heat load on CS is the sum of useful $Q_{s-1}$ and useless $Q_{u s}$ load:

$$
Q_{f u l}=Q_{s-1}+Q_{u s} .
$$


Useless heat load is a combination of the heat coming through thermal insulation $Q_{i z}$, and the heat transferred by gas flows into WBC zone $Q_{k o n w}$. The biggest amount of warmer gas comes to WBC zone through the doors. Cabin door are opened twice during the procedure: for patient's entrance and exit. In single-seated cryo saunas an atmospheric air comes through the opened doors. It should be replaced by nitrogen vapors in the beginning of the procedure. The total amount of heat coming by atmospheric air for one procedure into $1 \mathrm{~m}^{3}$ of single-cabin volume is

$$
Q_{\text {konw }}=\rho_{1} c_{k o n w}\left(T_{k o n w}-T_{1}\right),
$$

where $\rho_{1}$ - density of cooling gas at nominal temperature of WBC zone, $\mathrm{kg} / \mathrm{m}^{3} ; T_{1}$ - nominal temperature of WBC zone, $\mathrm{K} ; c_{\text {konw }}$ - heat capacity of gas coming into WBC zone, $\mathrm{J} /(\mathrm{kg} \cdot \mathrm{K})$; $T_{\text {konw }}$ - temperature of gas coming into WBC zone, $\mathrm{K}$.

Convective heat gain into the cabin and airlock cumber of multi-seated WBC unit is calculated in an analogous way. Atmospheric air fills the airlock cumber at the patients' entrance and exit to capacity. A relative warm air form lockchamber (LC) $\left(t_{L C}=-60^{\circ} \mathrm{C}\right)$ comes into main chamber (MC), where it is mixed with a cooler air $\left(-130 \leq t_{M C} \leq-110{ }^{\circ} \mathrm{C}\right)$ in the ratio of $1 / 1$. Following the mixing air temperature in LC and $\mathrm{MC}$ reaches the average temperature level

$$
\begin{aligned}
& \bar{t}=0,5\left(T_{M C}+T_{L C}\right) ; \\
& -95 \leq \bar{t} \leq-85{ }^{\circ} \mathrm{C} .
\end{aligned}
$$

Due to temperature increase air density in the main cabin decreases by $0.5 \mathrm{~kg} / \mathrm{m}^{3}$. After closing the transfer hatch the temperature in $\mathrm{MC}$ decreases gradually to nominal level, and air density increases. To maintain normal pressure level additional $0.5 \mathrm{~kg} / \mathrm{m}^{3}$ of air should be supplied to the volume. This air comes into MC from LC and adds additional heat. One opening of the transfer hatch between $\mathrm{MC}$ and $\mathrm{LC}$ results in additional $116 \mathrm{~kJ} / \mathrm{m}^{3}$ of heat comes into $\mathrm{MC}$ volume with gas flow from LC. As for one procedure the doors between $\mathrm{LC}$ and $\mathrm{WC}$ are opened twice convection heat gain into $\mathrm{MC}$ is $232 \mathrm{~kJ} / \mathrm{m}^{3}$ [7]. For one procedure LC filing is repeated twice, $256 \mathrm{~kJ} / \mathrm{m}^{3}$ coming into LC volume. Specific heat gain by convection in single-seated cabin is $365 \mathrm{~kJ} / \mathrm{m}^{3}$.

Heat comes from thermal insulation of $\mathrm{LC}$ and $\mathrm{MC}$. The influence of heat flow through insulation in multi-seated and single-seated unit differs significantly. Multi-seated cabin has a precooling stage of 2-3 hours. At this stage cooling of thermal insulation takes place. During the procedures only the heat transferred by thermal conductivity comes from insulation $\left(47 \mathrm{~kJ} / \mathrm{m}^{3}\right)$.

Single-seated unit has no mode of insulation cooling. After each procedure single-seated cabin is filled with atmospheric air, therefore, in the beginning of the procedure the temperature of inner surface equals the temperature of ambient air. During the procedure internal surface of the insulation is refrigerated to the temperature close to the nominal temperature of WBC zone. A great amount of heat accumulated by insulation is released during this process. Negative effect of the insulation is even more pronounced due to by the fact that the volume of single-seated cabin is less than $0.5 \mathrm{~m}^{3}$. In the cabins of small volume the specific surface of setting is $6.5 \mathrm{~m}^{2} / \mathrm{m}^{3}$ compared to only $2.4 \mathrm{~m}^{2} / \mathrm{m}^{3}$ for multiseated cabins. Due to the combined effect of the all above factors specific heat gain form the wall of single-seated unit is 10 times as much as in multi-seated unit (Table 2).

Table 2

Heat gain for one procedure in $\mathrm{WBC}$ zone of single and multi-seated unit $\left(\mathrm{kJ} / \mathrm{m}^{3}\right)$

\begin{tabular}{|l|c|c|}
\hline \multicolumn{1}{|c|}{ Sources of heat } & $\begin{array}{c}\text { Single- } \\
\text { seated unit }\end{array}$ & $\begin{array}{c}\text { Multi- } \\
\text { seated } \\
\text { unit }\end{array}$ \\
\hline Convection heat supply & 364 & 488 \\
\hline Heat from patients body surface & 1460 & 279 \\
\hline Heat from or thermal cooling of WBC zone & 493 & 47 \\
\hline TOTAL & 2317 & 814 \\
\hline
\end{tabular}

In Table 2 the values of specific heat gain from patient's body surface are given. In single-seated cabin the gain of specific heat from patient's body surface is five times more. It results from the high compactness of patient's positioning in a cabin. One patient takes $0.5 \mathrm{~m}^{3}$ of single-seated cabin volume. In multi-seated units one patient takes up to $2 \mathrm{~m}^{3}$ of LC and MC volume. Specific heat gain form patient's body surface in single-seated units is 5.2 times as much as in multiseated ones [7].

The data from Table 2 allow estimating energy efficiency of multi-seated and single-seated units by calculating thermal coefficient of efficiency (TCE)

$$
\eta_{H}=\frac{Q_{s-1}}{Q_{f u l}} .
$$

TCE for single-seated unit is 0.63 , and the one for multiseated unit is 0.34 . Contrary to common belief single-seated units are nearly twice as more economical as the multi-sedated unit.

\section{Energy consumption to remove heat load from $W B C$ zone}

The power of heat flow to be removed form WBC zone is defined from the formula

$$
q_{f u l}=\frac{N \cdot F_{s} \cdot Q_{s-1}}{\tau \cdot \eta_{H}},
$$

where $N$ - the number pf patients in a cabin; $F_{s}$ — average area of patients body surface, $\mathrm{m}^{2} ; \tau$ - procedure time, $\mathrm{s}$.

For the simplicity we can take $N=1, F_{s}=1.6 \mathrm{~m}^{2}, \tau=180 \mathrm{~s}$. Then, taking into account TCE values, the power of heat flow in multi-seated unit is $11.8 \mathrm{~kW}$, in single- seated $6.4 \mathrm{~kW}$ [7].

This heat load should be removed from the temperature level of $-130^{\circ} \mathrm{C}$. When the temperature decreases, the energy for heat load removal increases. The ratio of removed power to the electrical energy consumption is referred to as coefficient of performance

$$
\varepsilon=q_{f u l} / n_{e} .
$$

At the temperature level of $-130{ }^{\circ} \mathrm{C} \varepsilon=0.25$, that means the power of the cooling system has to be for times as many as the power of the heat load. In single-seated unit a cooling system of $26 \mathrm{~kW}$ power is necessary, and for multi-seated unit 
the electric power per patient is $47 \mathrm{~kW}$. For five-seated unit a refrigerator of $235 \mathrm{~kW}$ power is necessary.

The above results explain why the systems with nitrogen cooling are so popular. At the temperature level of $-130{ }^{\circ} \mathrm{C}$ cooling capacity of liquid nitrogen (LN) is $q_{L N}=260 \mathrm{~kJ} / \mathrm{kg}$. Liquid nitrogen consumption in NCS is defined from the equation

$$
g_{L N}=\frac{q_{f u l}}{q_{L N}} .
$$

For single-seated cabin nitrogen consumption in NCS is $0.025 \mathrm{~kg} / \mathrm{s}$ or $4.45 \mathrm{~kg}$ per procedure. In five-seated unit design LN consumption is $0.025 \mathrm{~kg} / \mathrm{s}$ or $41 \mathrm{~kg}$ per procedure. Such an expenditure of $\mathrm{LN}$ can be put into practice, at the same time refrigerators of 47 and $235 \mathrm{~kW}$ power require additional costs to connect them to power line $[7,8]$.

The above values or power or refrigerating medium consumption are much higher than the ones stated by manufacturers, only CRYON single-seated cryo sauna being the exception. In the latter $\mathrm{LN}$ consumption pre procedure is $4.5 \mathrm{~kg}$. The power consumption values of the other manufacturers' units is far less than the design ones. The certificate of KR-2005 five-seated unit (Creator Company, Poland) declares that LN consumption per 10 procedures is $100 \mathrm{~kg}$ [10]. Insufficient refrigerating medium consumption in NCS is not enough for cryostatting MC at the nominal temperature level; when the patients enter $\mathrm{MC}$ the air temperature increases more than by $60^{\circ} \mathrm{C}$ and have no time to reach nominal value to the end of the procedure.

The situation with NFCS units is even worse in terms of power supply. Zimmer Midizin Systeme five-seated unit (Zimmer GmbH, Germany) consumes $14 \mathrm{~kW}$ of electricity in the main procedural mode. The unit maintains the temperature of $-110^{\circ} \mathrm{C}$ only. At such a temperature level coefficient of performance is 0.37 , so $14 \mathrm{~kW}$ of electric power allows removing $5.2 \mathrm{~kW}$ of heat load. In addition, the unit allows only five procedures of three min. per hours, which means the real NFCS load is 0.25 form continuous operation conditions. Taking everything into consideration, NFCS heat removing capacity at the temperature level of $-110{ }^{\circ} \mathrm{C}$ increases to $21 \mathrm{~kW}$. However, power shortage is more than $50 \%$ under all assumptions [7].

\section{Conclusion}

The above analysis of energy and refrigerating medium consumption for WBC procedures demonstrates that for WBC to work in an efficient way it is necessary for power supply of CS to meet the technological heat load.

Calculated NFCS electric power for single-seated cryo saunas is $26 \mathrm{~kW}$. In multi-seated systems $47 \mathrm{~kW}$ of for every patient should be provided.

Taking in to account the values obtained the production of effective WBC units with the use of NFCS is unprofitable. Refrigerators with such a power are too expensive, and highqualified technical personal is required to connect them to electric power grid.

Single-seated cryo saunas with NCS should consume at least $4.5 \mathrm{~kg}$ of liquid nitrogen per patient. In multi-seated systems the nitrogen consumption per patent is as less as 8.1 $\mathrm{kg}$, refrigerating medium consumption in precooling mode being not taken into account in calculations.

As insufficient refrigerating medium supply therapeutic reduces effect of $\mathrm{WBC}$ procedures it is inadmissible to economize on liquid nitrogen.

\section{References}

1. Rymaszewska J., Urbańska K. M., Szcześniak D., Stańczykiewicz B., Trypka E., Zabłocka A. The improvement of memory deficits after whole-body cryotherapy - the first report. CryoLetters. 2018.39 (3), 166-176.

2. Greenwald, E., Christman, M., Penn, L., Brinster, N., Liebman, T. Cold panniculitis: Adverse cutaneous effect of whole-body cryotherapy. JAAD Case Rep. 2018. 4:344-345.

3. Krueger M., Costello J. T., Achtzehn S, Dittmar K. H., Mester J., Whole-body cryotherapy $\left(-110^{\circ} \mathrm{C}\right)$ following high-intensity intermittent exercise does not alter hormonal, inflammatory or muscle damage biomarkers in trained males Cytokine (IF 3.514) Pub Date: 2018-07-19, DOI: 10.1016/j. cyto. 2018.07.018.

4. Polidoria G., Cuttellb S., Hammondc L., Langdond D., Legrande F., Taiara R., Boyerf F. C., Costello J. T., Should Whole Body Cryotherapy sessions be differentiated between women and men? A preliminary study on the role of the body thermal resistance. August 2018, p. 60-64, Medical Hypotheses DOI: 10.1016/j. mehy. 2018.08.017

5. Poppendieck W., Faude O., Wegmann M., Meyer T., Cooling and Performance Recovery o Trained Athletes: A MetaAnalytical Review. International Journal of Sports Physiology and Performance. 2013. vol. 8, p. 227-242.

6. Shiman A. G., Kiryanova V. V., Maksimov A. V., Baranov A. Yu. Clinical and physiological aspects of the use of cryotherapy. Bulletin of St. Petersburg State medical Academy. I. I. Mechnikov. 2001. No. 1, Рp. 27-35. (in Russian). [Шиман А. Г., Кирьянова В. В., Максимов А. В., Баранов А. Ю. Клинико-физиологические аспекты применения криотерапии // Вестник СПб Государственной медицинской академии им. И. И. Мечникова. 2001. № 1, С. 27-35.]

7. Baranov A. Yu. Low-temperature installation for medical purposes. Part 1. Apparatus for the General cryotherapeutic influence: a training manual. SPb.: ITMO University, 2016. 178 p. (in Russian). [Баранов А. Ю. Низкотемпературные установки медицинского назначения. Ч. 1. Аппараты для общего криотерапевтического воздействия: учебное пособие. СПб.: Университет ИТМО, 2016. 178 с.]

8. Baranov A. Yu., Baranov V. A., Malysheva T. A. Energy bases of cryotherapy equipment effectiveness. Physiotherapy, balneology and rehabilitation. 2005. No 2, p. 29-31. (in Russian). [Баранов А. Ю., Баранов В. А., Малышева Т. А. Энергетические основы эффективности криотерапевтической аппаратуры // Физиотерапия, бальнеология и реабилитация. 2005. № 2, c. 29-31.]

9. Yamauchi Y., Yamauchi T., Miura K., The analgesic effects of $-170^{\circ} \mathrm{C}$ whole body cryo-therapy on rheumatoid arthritis (R. A.); curable/ IASP, Pain, Vol. 30, Supplement 1, 1987, P. S261.

10. Zagrobelny Z. Krioterapia miejscowa I ogolnoustrojowa, Urban\&Partner, Wroclaw, 2003, 189 p.

11. Baranov A. Yu., Malysheva T. A. Simulation of skin cryotherapy. Journal of International Academy of Refrigeration. 2017. № 1. p. 84-88. DOI: 10.21047/1606-4313-2017-16-1-84-88. (in Russian). [Баранов А. Ю., Малышева Т. А. Моделирование процесса охлаждения поверхности кожного покрова пациента // Вест- 
ник Международной академии холода. 2017. № 1. С. 84-88. DOI: 10.21047/1606-4313-2017-16-1-84-88]

12. Mahanek A. A., Levin M. L., Dragun V. L. Thermophysical aspects of General gas cryotherapy. Vesti NAS of Belarus. Ser. Phys.-tech. sciences. 2011. No. 3. C. 59-71. (in Russian). [Maханёк А. А., Левин М. Л., Драгун В. Л. Теплофизические аспекты общей газовой криотерапии // Вести НАН Беларуси. Сер. физ.-техн. наук. 2011. № 3. С. 59-71.]

13. Baranov A. Yu., Malysheva T. A. Experimental verification of the results of measuring the surface temperature of the skin of the patient before and after the General cryotherapy. Physical therapy and sports medicine. 2016. No 4 (136). P. 40-46. (in Russian). [Баранов А. Ю., Малышева Т. А. Эксперимен- тальная проверка результатов измерения температуры поверхности кожного покрова пациента до и после общего криотерапевтического воздействия // Лечебная физкультура и спортивная медицина 2016. № 4 (136). С. 40-46.]

14. Westerlund T., Oksa J., Smolander J., Mikkelsson M. Thermal responses during and after whole-body cryotherapy. $J$ Therm Biol. 2003. P. 601-608.

15. Savica M., Fonda B., Sarabona N., Actual temperature during and thermal response after whole-body cryotherapy in cryocabin. Journal of Thermal Biology, 2013.38:186-191.

16. Greenwald E., Christman M., Penn L., Brinster N., Liebman T. Cold panniculitis: Adverse cutaneous effect of whole-body cryotherapy. JAAD Case Rep., 2018. 4:344-345.

\section{Сведения об авторах}

\section{Баранов Александр Юрьевич}

д. т. н, профессор факультета низкотемпературной энергетики Университета ИТМО, 191002, Санкт-Петербург, ул. Ломоносова, 9, abaranov@corp.ifmo.ru

\section{Филатова Ольга Александровна}

аспирант факультета низкотемпературной энергетики Университета ИТМО, 191002, Санкт-Петербург, ул. Ломоносова, 9, oashestakova@corp.ifmo.ru

\section{Василенок Анна Владимировна}

аспирант факультета низкотемпературной энергетики Университета ИТМО, 191002, Санкт-Петербург, ул. Ломоносова, 9, Vasilenok_Anna@mail.ru

\section{Сафонов Александр Владимирович}

аспирант факультета низкотемпературной энергетики Университета ИТМО, 191002, Санкт-Петербург, ул. Ломоносова, 9, safonoff_sanya@corp.ifmo.ru

\section{Соколова Екатерина Владимировна}

старший преподаватель факультета низкотемпературной энергетики Университета ИТМО, 191002, Санкт-Петербург, ул. Ломоносова, 9, evlogvinenko@corp.ifmo.ru

\section{Information about authors}

Baranov Aleksandr Yurievich

D. Sc., Professor of Faculty of Cryogenic Engineering of ITMO University, 191002, Russia, St. Petersburg, Lomonosov str., 9, abaranov@corp.ifmo.ru

\section{Filatova Olga Aleksandrovna \\ Postgraduate Student of Faculty of Cryogenic Engineering of ITMO University, 191002, Russia, St. Petersburg, Lomonosov str., 9, oashestakova@corp.ifmo.ru}

\author{
Vasilenok Anna Vladimirovna \\ Postgraduate Student of Faculty of Cryogenic Engineering of ITMO \\ University, 191002, Russia, St. Petersburg, Lomonosov str., 9, \\ Vasilenok_Anna@mail.ru
}

\section{Safonov Aleksandr Vladimirovich}

Postgraduate Student of Faculty of Cryogenic Engineering of ITMO University, 191002, Russia, St. Petersburg, Lomonosov str., 9, safonoff_sanya@corp.ifmo.ru

\section{Sokolova Ekaterina Vladimirovna}

Senior lecturer of Faculty of Cryogenic Engineering of ITMO University, 191002, Russia, St. Petersburg, Lomonosov str., 9, evlogvinenko@corp.ifmo.ru

\section{О Перечне рецензируемых научных изданий *}

В соответствии с приказом Минобрнауки России от 25 июля 2014 г., 1 декабря 2015 г. сформирован Перечень рецензируемых научных изданий, в которых должны быть опубликованы основные научные результаты диссертаций на соискание ученой степени кандидата наук, на соискание ученой степени доктора наук.

Издания, текущие номера которых или их переводные версии входят хотя бы в одну из международных реферативных баз данных и систем цитирования Web of Science, Scopus, PubMed, MathSciNet, zbMATH, Chemical Abstracts, Springer или GeoRef считаются входящими в Перечень по отраслям науки, соответствующим их профилю.

Вестник Международной академии холода включен в Перечень по международной реферативной базе Chemical Abstracts.

*На сайте ВАК, в справочной информаџии об изданиях, входящих в международные реферативные базы данных и системы циитирования (по состоянию на 03.08.2018) Вестник МАХ опубликован под № 359. 